\title{
Evaluating the Effect of Lignocellulose-Derived Microbial Inhibitors on the Growth and Lactic Acid Production by Bacillus coagulans Azu-10
}

\author{
Mohamed Ali Abdel-Rahman 1,2,*, Saad El-Din Hassan ${ }^{1}{ }^{\circledR}$, Amr Fouda ${ }^{1}\left({ }^{\circledR}\right.$, Ahmed A. Radwan ${ }^{1}$, \\ Mohammed G. Barghoth ${ }^{1}$ and Salha G. Desouky ${ }^{3}$ \\ 1 Botany and Microbiology Department, Faculty of Science, Al-Azhar University, Nasr City, Cairo 11651, Egypt; \\ Saad.el-din.hassan@umontreal.ca (S.E.-D.H.); amr_fh83@azhar.edu.eg (A.F.); \\ ahmedradwan@azhar.edu.eg (A.A.R.); mohamed_gamal.sci@azhar.edu.eg (M.G.B.) \\ 2 Al-Azhar Center for Fermentation Biotechnology and Applied Microbiology, Al-Azhar University, Nasr City, \\ Cairo 11651, Egypt \\ 3 Department of Botany and Microbiology, Faculty of Science, Suez University, Suez 41522, Egypt; \\ abo_bara2w@yahoo.com \\ * Correspondence: mohamedali@kyudai.jp
}

Citation: Abdel-Rahman, M.A.; Hassan, S.E.-D.; Fouda, A.; Radwan, A.A.; Barghoth, M.G.; Desouky, S.G. Evaluating the Effect of Lignocellulose-Derived Microbial Inhibitors on the Growth and Lactic Acid Production by Bacillus coagulans Azu-10. Fermentation 2021, 7, 17. https://doi.org/10.3390/ fermentation7010017

Received: 23 December 2020

Accepted: 24 January 2021

Published: 27 January 2021

Publisher's Note: MDPI stays neutral with regard to jurisdictional claims in published maps and institutional affiliations.

Copyright: (C) 2021 by the authors Licensee MDPI, Basel, Switzerland. This article is an open access article distributed under the terms and conditions of the Creative Commons Attribution (CC BY) license (https:/ / creativecommons.org/licenses/by/ $4.0 /)$.

\begin{abstract}
Effective lactic acid (LA) production from lignocellulosic biomass materials is challenged by several limitations related to pentose sugar utilization, inhibitory compounds, and/or fermentation conditions. In this study, a newly isolated Bacillus coagulans strain Azu-10 was obtained and showed homofermentative LA production from xylose with optimal fermentation conditions at $50{ }^{\circ} \mathrm{C}$ and $\mathrm{pH}$ 7.0. Growth of strain Azu-10 and LA-fermentation efficiency were evaluated in the presence of various lignocellulose-derived inhibitors (furans, carboxylic acids, and phenols) at different concentrations. Furanic lignocellulosic-derived inhibitors were completely detoxified. The strain has exhibited high biomass, complete xylose consumption, and high LA production in the presence of 1.0-4.0 g/L furfural and 1.0-5.0 g/L of hydroxymethyl furfural, separately. Moreover, strain Azu-10 exhibited high LA production in the presence of 5.0-15.0 g/L acetic acid, $5.0 \mathrm{~g} / \mathrm{L}$ of formic acid, and up to $7.0 \mathrm{~g} / \mathrm{L}$ of levulinic acid, separately. Besides, for phenolic compounds, $p$-coumaric acid was most toxic at $1.0 \mathrm{~g} / \mathrm{L}$, while syringaldehyde or $p$-hydroxybenzaldehyde, and vanillin at $1.0 \mathrm{~g} / \mathrm{L}$ did not inhibit LA fermentation. The present study provides an interesting potential candidate for the thermophilic LA fermentation from lignocellulose-derived substrates at the industrial biorefinery level.
\end{abstract}

Keywords: lactic acid; lignocellulose-inhibitors; furans; Bacillus coagulans; xylose; thermophilic fermentation

\section{Introduction}

Lactic acid (LA) is a chemical compound with various industrial applications; besides, it can be used as a monomer for poly-lactic acid that is a biodegradable material alternative to petrochemical plastics. LA can be commercially produced either by chemical or biological syntheses. Petrochemical resources are utilized during the chemical route to produce a DL-racemic mixture, while the biotechnological route exploits renewable biomass and produces optically pure isomers using specific microorganisms [1].

Lignocellulosic feedstock for LA production by microbial fermentation has recently gained much interest due to its abundance, sustainability, avoidance of food crops' utilization, environmental impact, and cost-effectiveness production process [2]. This material mainly consists of cellulose, hemicellulose, and lignin. Cellulose and hemicellulose are potential sources of fermentable sugars for LA, while lignin is a non-fermentable phenolic compound [2]. Obtaining fermentable sugars from such biomass usually requires pretreatments by physical or chemical methods for delignification and isolation of cellulose fraction 
by hydrolysis of hemicellulose, followed by the saccharification of pretreated biomass by cellulosic enzymes to sugars. Both hexose and pentose sugars can be metabolized for LA fermentation [3].

However, cost-effective utilization of lignocellulose materials has faced several limitations related to biomass components, microbial strains, and fermentation conditions [4]. Firstly, the utilization of harsh thermo-chemical pretreatment methods using acids, alkali treatment, or steam explosion to loosen up the complex structure of lignocellulose materials [5-7]. Regarding different pretreatment methods and biomass components, partial degradation of lignocellulose-derived substrates may lead to the generation of various amounts of the inhibitory compounds such as furans (furfural and 5hydroxymethylfurfural (HMF)), weak acids, or phenolic compounds [8,9]. Most of these compounds act as enzymatic saccharification retardants or microbial growth and LA fermentative inhibitors. Detoxification of the pretreated lignocellulosic biomass is usually performed to alleviate the inhibition effect on LA producers and to enhance the production rates [10]. Therefore, screening for potent strains susceptible and tolerant to biomassderived inhibitors or having the ability to detoxify such inhibitors is of great interest. Second, most of the LA-producing strains cannot utilize xylose (the second most abundant sugar next to glucose) [11]. However, if utilized, most LA-producing bacteria metabolized it heterofermentative by the phosphoketolase pathway that produces several by-products such as acetic acid, formic acid, or $\mathrm{CO}_{2}$, along with low LA yield (the maximum theoretical $0.6 \mathrm{~g}$ lactate per gram of xylose) that consequently increases the purification cost of LA. Thus, homofermentative strains that can convert xylose into LA as a major product by the pentoses phosphate (PP) pathway are advantageous for the industrial-scale production of LA with high yield [12]. Finally, most of the reported LA-producers are mesophilic, which might retard the effective simultaneous saccharification and fermentation (SSF) process due to the incompatibility of optimal temperature for saccharifying cellulosic enzymes and microbial producers. Mesophilic conditions retard open fermentation processes, increase the risk of microbial contamination, and decrease fermentation efficiency; therefore, thermophilic LA producers are desirable [4,13].

This work focused on potential solutions to maximize the benefits of using lignocellulosic biomass for effective LA production. This study aimed to isolate a thermophilic, xylose-utilizing and inhibitor-resistant LA-producing bacterium. Screening the tolerance and detoxification abilities of this strain towards various lignocellulose-derived inhibitors (furans, carboxylic acids, and phenols) at different concentrations was evaluated. Their effects on bacterial growth and the outcomes on LA production efficiency and physiological kinetic parameters were investigated. The present study provides an interesting candidate for LA production at an industrial level in the future biorefineries.

\section{Materials and Methods}

\subsection{Bacterial Isolation and Fermentative Media}

Modified de Man, Rogosa, and Sharpe (mMRS) medium containing xylose was used for cell growth, inoculum preparation, and fermentations. This medium is composed of g/L: xylose, 22.0; yeast extract, 5.0; peptone, 10.0; beef extract, 8.0; $\mathrm{K}_{2} \mathrm{HPO}_{4}, 2.0 ; \mathrm{MgSO}_{4}$, $0.1 ; \mathrm{MnSO}_{4}, 0.05$; sodium acetate, 5.0; ammonium citrate, 2.0, and tween $80,1.0 \mathrm{~mL}$, as previously described [14]. The medium $\mathrm{pH}$ was adjusted to a specific value using $5 \mathrm{~N} \mathrm{HCl}$ and $5 \mathrm{~N} \mathrm{NaOH}$, as indicated in each experiment. All chemicals were purchase from Sigma Aldrich and were used as received.

Soil samples were collected from different localities in Egypt. For bacterial isolation, one gram of each soil sample was suspended separately in $100 \mathrm{~mL}$ of sterilized saline solution $(0.85 \% \mathrm{NaCl})$ and $10 \mathrm{~mL}$ was transferred to $250 \mathrm{~mL}$ Erlenmeyer flasks containing $100 \mathrm{~mL}$ of mMRS-xylose supplemented with $5.0 \mathrm{~g} / \mathrm{L}$ acetic acid and $1.0 \mathrm{~g} / \mathrm{L}$ furfural at an initial $\mathrm{pH}$ of 7.0. The flasks were incubated at $50{ }^{\circ} \mathrm{C}$ for $72 \mathrm{~h}$. Culture aliquots were spread evenly on mMRS agar plates containing $22 \mathrm{~g} / \mathrm{L}$ xylose and incubated at $50{ }^{\circ} \mathrm{C}$ under aerobic conditions for $72 \mathrm{~h}$. Bacterial colonies were individually picked and streaked on 
another plate until single colonies were obtained. Catalase-positive isolates were selected for primary screening to examine xylose utilization, LA concentration, LA yield, and optical purity. The most potent isolate (Azu-10) was maintained in mMRS medium containing approximately $22.0 \mathrm{~g} / \mathrm{L}$ xylose for immediate use or preserved in $30 \%$ glycerol at $-80{ }^{\circ} \mathrm{C}$.

\subsection{Characterization and Identification of Bacterial Strain}

Physiological characteristics of isolate Azu-10 were determined using the Analytical Profile Index of 50 Carbohydrates [API 50 CHL test kit (bioM'erieux, Marcy l' France)] according to the manufacturer's instructions. Molecular identification was performed by the extraction of genomic DNA using the modified method according to Miller et al. [15]. The 16S rRNA gene fragments were analyzed using universal primers of 27f (5-GAGTTTGATCA CTGGCTCAG-3) and 1492r (5-TACGGCTACCTTGTTACGACTT-3) using genomic DNA as a template in a polymerase chain reaction (PCR). The PCR mixture contained $1 \times$ PCR buffer, $0.25 \mathrm{mM}$ dNTP, $0.5 \mathrm{mM} \mathrm{MgCl}$, $2.5 \mathrm{U}$ Taq DNA polymerase (QIAGEN), $0.5 \mu \mathrm{M}$ of each primer, and $1 \mu \mathrm{g}$ of genomic DNA. DNA Engine Thermal Cycler (PTC-200, BioRad, Hercules, CA, USA) was used for PCR at the following conditions: hot starting performed at $94{ }^{\circ} \mathrm{C}$ for $3 \mathrm{~min}$, then 30 cycles of $94{ }^{\circ} \mathrm{C}$ for $0.5 \mathrm{~min}, 55^{\circ} \mathrm{C}$ for $0.5 \mathrm{~min}$, and $72{ }^{\circ} \mathrm{C}$ for $1 \mathrm{~min}$. The extension was performed for $10 \mathrm{~min}$ at $72{ }^{\circ} \mathrm{C}$. The PCR product was commercially sequenced using an ABI 3730xl DNA sequencer at Sigma Company. The sequence was then compared with those sequences in the GenBank database through BLASTN. Multiple sequence alignment was then performed on $1200 \mathrm{bp}$ of 16S rRNA gene fragments by the ClustalX 1.8 software package and the phylogenetic tree was established with a neighbor-joining method of the Kimura 2-parameter model to calculate genetic distance as the transitional and transversional substitution rates using MEGA (version 6.1; http:/ / www.megasoftware.net) software. The level of confidence was tested by bootstrap analysis for each branch at 1000 repeats. The Uchime2_NCBI tool was used to detect chimeras that are $>3 \%$ diverged from the closest sequences. The obtained 16S rRNA gene sequence of the strain Azu-10 was deposited in GenBank with an accession number of MK026975.

\subsection{Inoculum Preparation and Batch Fermentations}

For inoculum preparation, seed culture was prepared by transferring $1.0 \mathrm{~mL}$ of strain Azu-10 glycerol stock to a sterile tube containing $10 \mathrm{~mL}$ mMRS medium supplemented with $22 \mathrm{~g} / \mathrm{L}$ xylose and cultivated at $50{ }^{\circ} \mathrm{C}$ for $24 \mathrm{~h}$. A pre-culture was prepared by inoculating $4 \mathrm{~mL}$ of seed culture into $36 \mathrm{~mL}$ of the same mMRS medium in a $50 \mathrm{~mL}$ falcon tube at $50{ }^{\circ} \mathrm{C}$ for $18 \mathrm{~h}$. Fermentations were performed in a one-liter fermenter (Biott, Tokyo, Japan) with a $0.4 \mathrm{~L}$ working volume that inoculated at $10 \%$ from the pre-culture broth in mMRS medium containing $22 \mathrm{~g} / \mathrm{L}$ xylose with agitation at $200 \mathrm{rpm}$.

To investigate LA production at different $\mathrm{pH}$ values, fermentations were performed at $50{ }^{\circ} \mathrm{C}$ without $\mathrm{pH}$ control (initial $\mathrm{pH} 7.0$ ) or under controlled $\mathrm{pH}$ conditions $(5.0,6.0,6.5,7.0$, $7.5,8.0$, and 9.0) that were maintained by the addition of $5 \mathrm{~N} \mathrm{NaOH}$ as a neutralizing agent.

To investigate the effect of temperature on LA production, fermentations were conducted at different temperatures $\left(30,35,40,43,45,50,56,60\right.$, and $\left.63^{\circ} \mathrm{C}\right)$ under controlled pH conditions, 7.0.

To investigate the effect of inhibitors on biomass and LA fermentations at $50{ }^{\circ} \mathrm{C}$, $200 \mathrm{rpm}$, and pH 7.0 controlled by the addition of $5 \mathrm{~N} \mathrm{NaOH}$, different concentrations of furan compounds (furfural (1.0-5.0 g/L) and hydroxyl methyl furfural (1.0-6.0 g/L)), weak acid (acetic acid (5.0-20 g/L), formic acid (5.0-10 g/L), and levulinic acid (1.0-7.0 g/L)), and phenolic compounds (phenolic ketone, phenolic acids, and phenolic aldehydes; $p$-coumaric acid, syringaldehyde or $p$-hydroxybenzaldehyde $(1.0 \mathrm{~g} / \mathrm{L})$, and vanillin $(1.0$ and $3.0 \mathrm{~g} / \mathrm{L}))$ were separately supplemented to mMRS-xylose media. Samples were collected at different time intervals to analyze biomass, xylose, lactic acid, acetic acid, formic acid, ethanol, and inhibitor concentrations. 


\subsection{Analytical Methods}

The biomass was estimated based on optical density $\left(\mathrm{OD}_{562}\right)$ measurements obtained using a spectrophotometer (UV-1600 visible spectrophotometer, BioSpec, Shimadzu, Kyoto, Japan). Xylose and fermentation products were analyzed using high-performance liquid chromatography system (HPLC) (Agilent 1200 series chromatograph, USA) using a refraction index detector (RID-6A) and Biorad Aminex HPX-87H column $(300 \mathrm{~mm} \times 7.8 \mathrm{~mm}$ ) at $50{ }^{\circ} \mathrm{C}$. Sulfuric acid $(5 \mathrm{mM})$ was used as mobile phase at a flow rate of $0.6 \mathrm{~mL} / \mathrm{min}$. The injection volume of the sample was set at $20 \mu \mathrm{L}$. The specific growth rate $\left(\mu_{\max }\right)$ was calculated as the increase in biomass per unit of time: $\mu_{\max }\left(h^{-1}\right)=\ln \left(x_{2} / x_{1}\right) /\left(t_{2}-t_{1}\right)$, where $\mathrm{x}$ is biomass $\left(\mathrm{OD}_{562 \mathrm{~nm}}\right)$ obtained at each sample time, $\mathrm{t}(\mathrm{h})$. Consumed sugars were calculated by the difference between initial xylose concentration and residual xylose concentration $(\mathrm{g} / \mathrm{L})$. The LA yield $(\mathrm{g} / \mathrm{g})$ based on consumed sugars is calculated as the ratio of LA $(\mathrm{g} / \mathrm{L})$ to sugar xylose $(\mathrm{g} / \mathrm{L})$, LA productivity $(\mathrm{g} / \mathrm{L} \cdot \mathrm{h}))$ is defined as the ratio of lactic acid concentration $(\mathrm{g} / \mathrm{L})$ to the fermentation time $(\mathrm{h})$, and maximum LA productivity $(\mathrm{g} /(\mathrm{L} \cdot \mathrm{h}))$ was determined by the difference between LA concentrations of two respective samples divided by the time difference. Analysis of variance (ANOVA) was used to show the significant differences between treatments. The mean difference comparison between the treatments was subsequently analyzed by the Tukey HSD (honestly significant difference) test at $p<0.05$. Data analysis was performed using statistical package SPSS v17 (SPSS Inc., Chicago, IL, USA). All results presented are the means of three independent replicates.

\section{Results}

\subsection{Isolation and Identification of Isolate Azu-10}

Based on the isolation protocol, 14 isolates were obtained from different soil samples. The isolate Azu-10 showed the highest performance among other isolates as it produced the highest LA at $6.42 \mathrm{~g} / \mathrm{L}$ at a yield of $1.0 \mathrm{~g} / \mathrm{g}$ mMRS-xylose $(22 \mathrm{~g} / \mathrm{L})$ supplemented with a mixture of $5.0 \mathrm{~g} / \mathrm{L}$ acetic acid (carboxylic acid) and $1.0 \mathrm{~g} / \mathrm{L}$ furfural (furan). Therefore, it was selected as the best candidate in the present study. Isolate Azu-10 was isolated from a fertile soil sample collected from Giza governorate, Egypt. Physiological characterization showed that isolate Azu-10 is Gram-positive, endospore-forming rods, catalase-positive, grows at $30-60{ }^{\circ} \mathrm{C}$, and a $\mathrm{pH}$ of $5.0-8.0$. The sugar fermentation pattern was investigated using API 50 CHL (Table S1, see Supplementary Materials). Isolate Azu-10 was able to ferment ribose, glucose, arabinose, mannose, galactose, fructose, saccharose, trehalose, starch, maltose, and cellobiose, which could be very valuable for effective utilization of renewable and lignocellulosic resources. This isolate is negative for glycerol, inulin, melibiose, glycogen, xylitol, and esculine fermentation. Variable characteristics were found for acid production from sorbitol, arbutine, raffinose, turanose, arabitol, and lactose.

Phylogenetic analysis (Figure S1, see Supplementary Materials) based on 16S rRNA gene sequence revealed that the isolate Azu-10 was closely related to Bacillus coagulans MF077122, AB240204, and MH392659 with 99.0\% similarity. Based on the phenotypic characteristics and $16 \mathrm{~S}$ rRNA gene similarity, the isolate Azu-10 was identified as Bacillus coagulans Azu-10.

\subsection{Effect of $\mathrm{pH}$ Values on Lactic Acid Fermentation from Xylose}

The growth and LA production by Azu-10 at non-controlled $\mathrm{pH}$ and controlled $\mathrm{pH}$ at different values were evaluated in mMRS medium containing $22.0 \mathrm{~g} / \mathrm{L}$ xylose at $50{ }^{\circ} \mathrm{C}$, as shown in Supplementary Table S2.

The $\mathrm{pH}$ was decreased from 6.88 to 4.30 after $24 \mathrm{~h}$ under uncontrolled $\mathrm{pH}$ fermentation conditions, resulting in a maximum $\mathrm{OD}_{562}$ of 3.14 and LA concentration of $7.50 \mathrm{~g} / \mathrm{L}$ at a LA yield of $1.02 \mathrm{~g} / \mathrm{g}$ after $24 \mathrm{~h}$. Compared to uncontrolled $\mathrm{pH}$ fermentations, significantly less biomass of $\mathrm{OD}_{562} 0.940$ was obtained when the $\mathrm{pH}$ was maintained at 5.0, which consequently lowered the LA concentration to $2.81 \mathrm{~g} / \mathrm{L}$ but LA yield was still high at $0.95 \mathrm{~g} / \mathrm{g}$ with very high residual xylose in the fermentation media. In contrast, controlled fermentation at $\mathrm{pH}$ 5.5-7.0 produced higher biomass $\left(\mathrm{OD}_{562} 4.54-9.42\right)$ with complete 
consumption of xylose achieving LA production at 20.5-22.0 g/L with homolactic fermentation of high LA yield (ranged $0.970-1.02 \mathrm{~g} / \mathrm{g}$ ). Varied concentrations of acetic acid were also produced that ranged $0.593-1.25 \mathrm{~g} / \mathrm{L}$ with almost no ethanol production, which was detected only at $0.14 \mathrm{~g} / \mathrm{L}$ in controlled fermentation of $\mathrm{pH}$ 6.5. The fermentation time was varied at these $\mathrm{pH}$ values, achieving the lowest fermentation time at $\mathrm{pH} 7.0$, where the LA productivities achieved its maximal value of $3.0 \mathrm{~g} / \mathrm{L} \cdot \mathrm{h})$. A sharp decrease in biomass of $\mathrm{OD}_{562}$ ranging $0.280-1.60$ was obtained when the fermentations were maintained at $\mathrm{pH}$ 7.5-9.0, which gives low LA production that ranged $0.469-0.955 \mathrm{~g} / \mathrm{L}$ at a very low yield, ranging $0.35-0.50 \mathrm{~g} / \mathrm{g}$.

Based on these results, the highest biomass was $\mathrm{OD}_{562} 9.42$ and LA productivity was $3.0 \mathrm{~g} /(\mathrm{L} \cdot \mathrm{h})$. The value of $\mathrm{pH} 7.0$ was considered as the optimal value for LA fermentation by Azu-10 and was used in the subsequent experiments.

\subsection{Effect of Temperature on Lactic Acid Fermentation from Xylose}

Strain Azu-10 was cultivated in mMRS medium containing xylose $(22.0 \mathrm{~g} / \mathrm{L})$ at temperatures ranging from 30 to $63{ }^{\circ} \mathrm{C}$ under a controlled $\mathrm{pH}$ of 7.0 using $5 \mathrm{~N} \mathrm{NaOH}$ as a neutralizing agent (Table 1). Complete xylose consumption was obtained between 30 and $55^{\circ} \mathrm{C}$ but little residual xylose at $7.04 \mathrm{~g} / \mathrm{L}$ was left in fermentation media at $60^{\circ} \mathrm{C}$ after $30 \mathrm{~h}$. Fermentations performed at $30-60{ }^{\circ} \mathrm{C}$ have resulted in high biomass $\left(\mathrm{OD}_{562}, 1.78-9.42\right)$, LA concentrations (17.5-21.9 g/L), and LA yields $(0.90-1.02 \mathrm{~g} / \mathrm{g}$ ) with varied little byproducts (acetic acid and ethanol) production. A higher amount of acetic acid was detected (ranged 2.30-4.57 g/L) at temperate $30-40{ }^{\circ} \mathrm{C}$ than $0.314-1.82 \mathrm{~g} / \mathrm{L}$ that were detected at $45-60{ }^{\circ} \mathrm{C}$. Ethanol was detected in lower amounts $(\leq 0.469 \mathrm{~g} / \mathrm{L})$ at $40-60^{\circ} \mathrm{C}$. Strain Azu-10 produced 21.5 and $17.5 \mathrm{~g} / \mathrm{L}$ LA with a high yield of 0.970 and $1.00 \mathrm{~g} / \mathrm{g}$ despite the low LA productivity of 2.69 and $0.580 \mathrm{~g} /(\mathrm{L} \cdot \mathrm{h})$ at 55 and $60{ }^{\circ} \mathrm{C}$, respectively. Fermentation at temperatures $>60{ }^{\circ} \mathrm{C}$ resulted in significantly lower $\mathrm{OD}_{562}$ values $(0.480 \mathrm{~g} / \mathrm{L})$, xylose consumption $(3.25 \mathrm{~g} / \mathrm{L})$, and LA concentration $(0.680 \mathrm{~g} / \mathrm{L})$. The highest LA productivity $(3.00 \mathrm{~g} /(\mathrm{L} \cdot \mathrm{h}))$ and the maximal productivity $(5.7 \mathrm{~g} /(\mathrm{L} \cdot \mathrm{h}))$ were obtained at $50^{\circ} \mathrm{C}$, among the temperatures tested. Based on the highest biomass and these above data, the optimal fermentation temperature of strain Azu- 10 was selected at $50{ }^{\circ} \mathrm{C}$ and resulted in a high $\mathrm{OD}_{562}$ value of 9.42 , LA concentration of $22.0 \mathrm{~g} / \mathrm{L}$, LA yield of $1.02 \mathrm{~g} / \mathrm{g}$, and LA productivity of $3.00 \mathrm{~g} /(\mathrm{L} \cdot \mathrm{h})$ with less by-product formation of acetic acid $(1.03 \mathrm{~g} / \mathrm{L})$, without ethanol or formic acid production.

Table 1. Effect of temperature on lactic acid (LA) fermentation efficiency by Bacillus coagulans Azu-10.

\begin{tabular}{|c|c|c|c|c|c|c|c|c|}
\hline $\begin{array}{l}\text { Temp. } \\
\left({ }^{\circ} \mathrm{C}\right)\end{array}$ & $\begin{array}{l}\text { Max. Biomass } \\
\left(\mathrm{OD}_{562 \mathrm{~nm}}\right)\end{array}$ & $\begin{array}{c}\text { Residual } \\
\text { Xylose (g/L) }\end{array}$ & $\begin{array}{c}\text { LA } \\
(\mathrm{g} / \mathrm{L})\end{array}$ & $\begin{array}{l}\text { Acetic Acid } \\
\text { (g/L) }\end{array}$ & $\begin{array}{l}\text { Ethanol } \\
(\mathrm{g} / \mathrm{L})\end{array}$ & $\begin{array}{l}\text { LA Yield } \\
\text { (g/g) }\end{array}$ & $\begin{array}{c}\text { LA } \\
\text { Productivity } \\
(\mathrm{g} /(\mathrm{L} \cdot \mathrm{h}))\end{array}$ & $\begin{array}{l}\text { Max. LA } \\
\text { Productivity } \\
\text { (g/(L.h)) }\end{array}$ \\
\hline 30 & $5.06 \pm 0.15$ & $<0.1$ & $20.5 \pm 1.05$ & $4.57 \pm 0.18$ & $<0.1$ & $0.900 \pm 0.025$ & $0.890 \pm 0.013$ & $1.70 \pm 0.12$ \\
\hline 35 & & $<0.1$ & $.4 \pm 1.01$ & $3.82 \pm 0.34$ & $<0.1$ & $0.900 \pm 0.013$ & $1.13 \pm 0.025$ & $0.796 \pm 0.10$ \\
\hline 40 & $2.68 \pm 0.32$ & $<0.1$ & $21.9 \pm 0.85$ & $2.30 \pm 0.65$ & $0.450 \pm 0.045$ & $0.910 \pm 0.024$ & $1.83 \pm 0.022$ & $2.13 \pm 0.34$ \\
\hline 45 & $2.90 \pm 0.21$ & $<0.1$ & $21.4 \pm 0.47$ & $1.82 \pm 0.13$ & $0.420 \pm 0.008$ & $0.970 \pm 0.018$ & $1.70 \pm 0.145$ & $2.62 \pm 0.51$ \\
\hline 50 & $9.42 \pm 0.39$ & $<0.1$ & $22.0 \pm 1.07$ & $1.03 \pm 0.16$ & 0.0 & $1.02 \pm 0.005$ & $3.00 \pm 0.023$ & $5.70 \pm 0.23$ \\
\hline 55 & $6.38 \pm 0.17$ & $<0.1$ & $21.5 \pm 0.83$ & $0.314 \pm 0.05$ & $0.388 \pm 0.007$ & $0.970 \pm 0.013$ & $2.69 \pm 0.245$ & $5.12 \pm 0.62$ \\
\hline 60 & $4.26 \pm 0.22$ & $7.04 \pm 0.35$ & $17.5 \pm 0.64$ & $0.430 \pm 0.04$ & $0.469 \pm 0.013$ & $1.00 \pm 0.023$ & $0.580 \pm 0.041$ & $1.66 \pm 0.22$ \\
\hline 63 & $0.480 \pm 0.09$ & $18.75 \pm 0.27$ & $0.680 \pm 0.15$ & $<0.06$ & $<0.1$ & $0.22 \pm 0.013$ & $0.030 \pm 0.005$ & $0.030 \pm 0.02$ \\
\hline
\end{tabular}

$\mathrm{OD}_{562 \mathrm{~nm}}$, optical density of cell growth at $562 \mathrm{~nm}$; LA, Lactic acid.

\subsection{Effect of Furan on Bacterial Growth and LA Fermentation}

To investigate the effect of lignocellulose-derived inhibitors on the LA fermentation by isolate Azu-10, growth, detoxifying, or resistance ability, and LA fermentation efficiency were examined in the MRS medium containing different concentrations of furan compounds: furfural (1.0-5.0 g/L) and hydroxyl methyl furfural (HMF) (1.0-6.0 g/L), individually. Strain Azu-10 showed relatively high biomass ( $\mathrm{OD}_{562}$ values) in the presence of 1.0-3.0 g/L furfural (Figure 1A-C) with $\mathrm{OD}_{562}$ values ranged 8.2-9.78 as compared to $\mathrm{OD}_{562}$ value 9.42 obtained in the absence of furan. A significant decrease in biomass was obtained 
at 4.0 and $5.0 \mathrm{~g} / \mathrm{L}$ furfural that was $\mathrm{OD}_{562} 4.78$ and 2.1, respectively (Figure 1D,E). On the other hand, $6.0 \mathrm{~g} / \mathrm{L}$ furfural completely inhibited LA fermentation by strain Azu-10. According to the bacterial growth, a $\mu_{\max }$ of $0.804 \mathrm{~h}^{-1}$ was obtained in the absence of inhibitors by Bacillus coagulans Azu-10 strain, while lower growth rates (ranged 0.158-0.649 $\mathrm{h}^{-1}$ ) were obtained with furfural inhibitors (Table 2). Although growth rates were reduced, complete consumption of xylose was achieved with 1.0-4.0 g/L furfural, while $6.14 \mathrm{~g} / \mathrm{L}$ of xylose was left in fermentation medium in the presence of $5.0 \mathrm{~g} / \mathrm{L}$ furfural (Figure 1A-E). Consequently, LA was produced at high titer (20.0-23.0 g/L) with high yield (0.956-1.04 g/g), LA productivities $(1.46-2.88 \mathrm{~g} /(\mathrm{L} \cdot \mathrm{h}))$, and maximal LA productivities $(2.16-5.02 \mathrm{~g} /(\mathrm{L} \cdot \mathrm{h}))$ in the presence of 1.0-4.0 g/L furfural. However, $15.9 \mathrm{~g} / \mathrm{L}$ of LA was produced in the presence of $5.0 \mathrm{~g} / \mathrm{L}$ furfural. Interestingly, strain Azu-10 showed an ability to detoxify/degrade furfural compounds up to $5.0 \mathrm{~g} / \mathrm{L}$ as no residual furfural was detected in these fermentation media. While in the batch fermentation with $6.0 \mathrm{~g} / \mathrm{L}$ furfural, $2.16 \mathrm{~g} / \mathrm{L}$ furfural was left with very low biomass $\left(\mathrm{OD}_{562}\right.$ of 0.042$)$, and no LA was produced.

Similarly, high biomass values (ranged 6.24-9.96) were obtained in the presence of 1.0-5.0 $\mathrm{g} / \mathrm{L}$ of HMF with relatively high $\mu_{\max }$ of $0.467-0.739 \mathrm{~h}^{-1}$ that was achieved in the presence of 1.0-4.0 g/L of HMF, while lower growth rates $\left(0.306 \mathrm{~h}^{-1}\right)$ were obtained with $5.0 \mathrm{~g} / \mathrm{L}$ HMF (Table 2). Xylose was completely consumed at all tested HMF concentrations (Figure 1F-J). High LA titer ranging from 19.5 to $20.1 \mathrm{~g} / \mathrm{L}$ at yield ranging 0.962-0.987, LA productivities ranging 1.11-2.44 $\mathrm{g} /(\mathrm{L} \cdot \mathrm{h})$, and maximum LA productivities ranging 2.08-3.91 $\mathrm{g} /(\mathrm{L} \cdot \mathrm{h})$ were obtained. Interestingly, the strain Azu-10 was complexly detoxifying/degrading the HMF up to $5.0 \mathrm{~g} / \mathrm{L}$, as indicated from Table 2. These results conclude the stability of strain Azu-10 towards furan inhibitors with crucial fermentation abilities.

\subsection{Effect of Carboxylic Acids on Growth and LA Fermentation}

To investigate the effect of carboxylic acid on Azu-10 growth, LA fermentation, different concentrations of acetic acid (5.0-20 g/L), formic acid (5.0-10 g/L), and levulinic acid (1.0-7.0 g/L) were separately supplemented to mMRS-xylose media, as shown in Figure 2 and Table 3.

Strain Azu-10 showed relatively high biomass in the presence of 5.0-15.0 g/L acetic acid with $\mathrm{OD}_{562}$ values ranging 6.34-8.64 (Figure 2A-C) with specific growth rates that ranged $0.401-0.454 \mathrm{~h}^{-1}$, while it was significantly reduced to $\mathrm{OD}_{562} 0.320$ with a specific growth rate of $0.030 \mathrm{~h}^{-1}$ with $20 \mathrm{~g} / \mathrm{L}$ acetic acids. Xylose was completely consumed at different consumption rates that were achieved after $10 \mathrm{~h}$ of fermentation in the presence of $5.0-10.0 \mathrm{~g} / \mathrm{L}$ acetic acid, while it took a longer time $(20 \mathrm{~h})$ in the presence of $15.0 \mathrm{~g} / \mathrm{L}$ acetic acid. On the other hand, no consumption was obtained at $20.0 \mathrm{~g} / \mathrm{L}$ acetic acid (Figure 2D). With 5.0-15.0 g/L acetic acid, high LA concentrations at 18.4-20.5 g/L were produced at a yield of $\sim 1.0 \mathrm{~g} / \mathrm{g}$ with LA productivities ranging 1.04-2.05 $\mathrm{g} /(\mathrm{L} \cdot \mathrm{h})$, and maximum LA productivities ranging 1.40-4.32 g/(L.h). Also, strain Azu-10 could tolerate high acetic acid production (without consumption) with the production of an extra small amount of acetic acid ranging $0.42-1.76 \mathrm{~g} / \mathrm{L}$, without ethanol or formic acid production (Table 3 , Figure 2A-D).

On the other hand, strain Azu-10 could not tolerate higher than $5.0 \mathrm{~g} / \mathrm{L}$ of formic acid while the growth and LA fermentation were completely inhibited in the presence of $10.0 \mathrm{~g} / \mathrm{L}$ of formic acid (Figure 2E,F). At $5.0 \mathrm{~g} / \mathrm{L}$ of formic acid, the strain showed high biomass at $\mathrm{OD}_{562}$ of 5.3 with complete consumption of xylose after $20 \mathrm{~h}$ and production of $19.2 \mathrm{~g} / \mathrm{L} \mathrm{LA}$ at a yield of $0.993 \mathrm{~g} / \mathrm{g}$, the productivity of $0.963 \mathrm{~g} /(\mathrm{L} \cdot \mathrm{h})$, and maximum productivity of $2.47 \mathrm{~g} /(\mathrm{L} \cdot \mathrm{h})$. Little by-products were detected of acetic acid $(1.13 \mathrm{~g} / \mathrm{L})$, without the formation of formic acid or ethanol.

Strain Azu-10 could grow effectively in the presence of various concentrations of levulinic acid (1.0-7.0 g/L) and exhibited biomass ranging 7.08-9.12 with a varied specific growth rate that ranged from 0.466 to $0.693 \mathrm{~h}^{-1}$. Complete sugar consumption was achieved in the tested concentrations after $8 \mathrm{~h}$ of fermentation with 1.0-5.0 g/L of levulinic acid and after $10 \mathrm{~h}$ in the presence of $7.0 \mathrm{~g} / \mathrm{L}$ of levulinic acid (Figure 2G-L). Production 
of high LA concentrations (18.1-20.2 g/L) with yields $(0.916-1.06 \mathrm{~g} / \mathrm{g})$, LA productivities $(1.95-2.47 \mathrm{~g} /(\mathrm{L} \cdot \mathrm{h}))$, and maximum LA productivities $(3.76-4.79 \mathrm{~g} /(\mathrm{L} \cdot \mathrm{h}))$ were achieved at all tested levulinic acid concentrations. Strain Azu-10 was stable to levulinic acid that was not degraded or detoxified, as indicated by the residual inhibitors that ranged from $91.6 \%$ to $98.8 \%$ of the originally tested concentrations (Table 3 ).
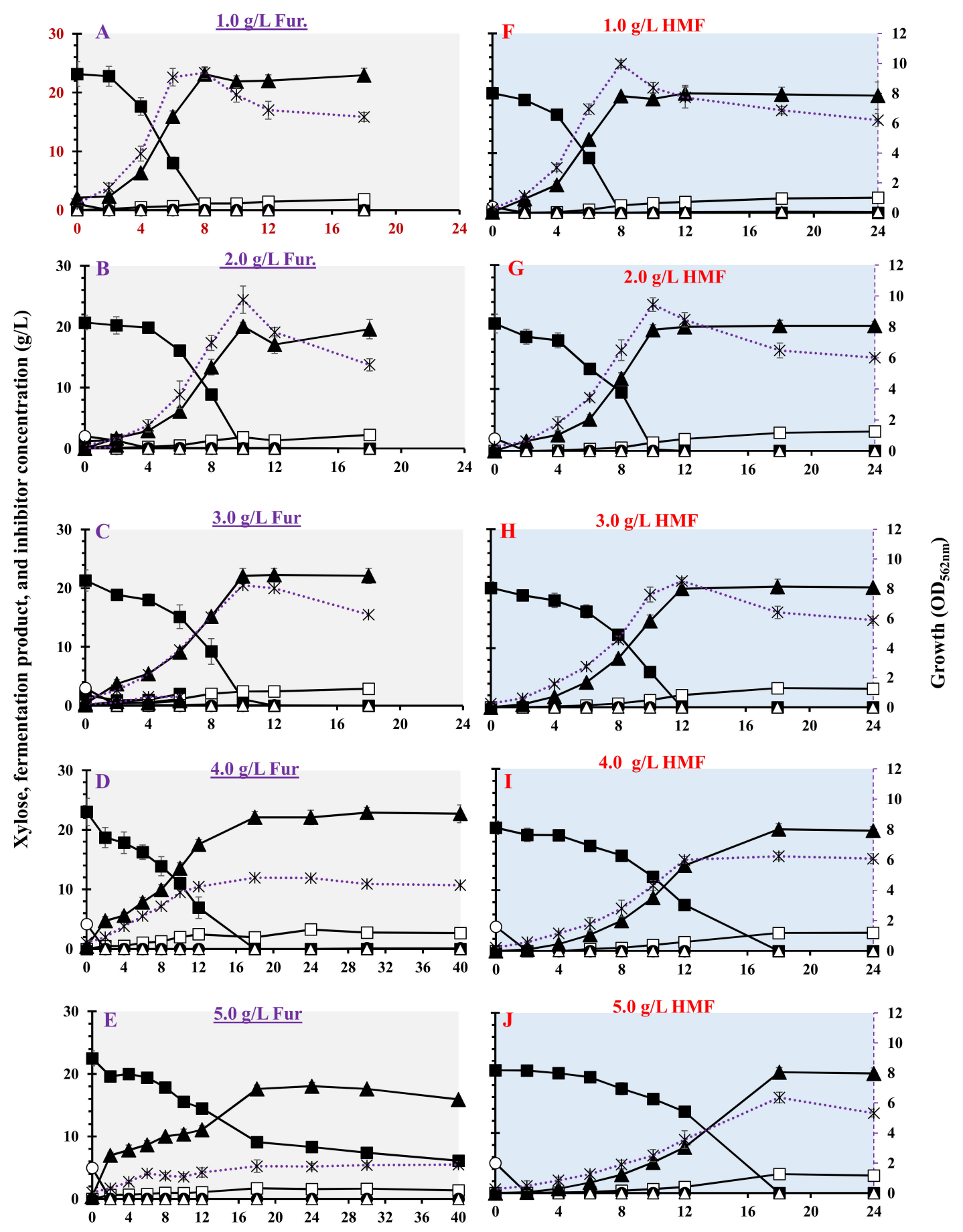

Fermentation time (h)

Figure 1. Effect of different concentrations of furfural (A-E) and HMF (F-J) on the growth and lactic acid production by Bacillus coagulans Azu-10. Symbols: $\mathbf{\square}$, xylose (g/L); $\square$, acetic acid (g/L); $\bigcirc$, inhibitor (Furfural or HMF, g/L); •, formic acid $(\mathrm{g} / \mathrm{L}) ; \Delta$, ethanol $(\mathrm{g} / \mathrm{L}) ; \boldsymbol{\Lambda}$, lactic acid $(\mathrm{g} / \mathrm{L}) ;{ }^{*}$, growth $\left(\mathrm{OD}_{562 \mathrm{~nm}}\right)$. The standard deviation is less than the size of symbols if no error bars are seen. 
Table 2. Effect of furans on lactic acid fermentation efficiency by Bacillus coagulans Azu-10.

\begin{tabular}{|c|c|c|c|c|c|c|c|c|c|c|c|}
\hline Furans & $\begin{array}{l}\text { Inhibitor } \\
\text { Conc. }(g / L)\end{array}$ & $\begin{array}{c}\text { Max. } \\
\text { Biomass } \\
\left(\mathrm{OD}_{562 \mathrm{~nm}}\right)\end{array}$ & $\begin{array}{l}\mu_{\max } \\
\left(h^{-1}\right)\end{array}$ & $\begin{array}{c}\text { Residual } \\
\text { Xylose (g/L) }\end{array}$ & $\begin{array}{c}\text { LA } \\
(\mathrm{g} / \mathrm{L})\end{array}$ & $\begin{array}{l}\text { Acetic Acid } \\
(\mathrm{g} / \mathrm{L})\end{array}$ & $\begin{array}{c}\text { Ethanol } \\
(\mathrm{g} / \mathrm{L})\end{array}$ & $\begin{array}{l}\text { LA Yield } \\
\text { (g/g) }\end{array}$ & $\begin{array}{c}\text { LA } \\
\text { Productivity } \\
(\mathrm{g} /(\mathrm{L} \cdot \mathrm{h}))\end{array}$ & $\begin{array}{c}\text { Max. LA } \\
\text { Productivity } \\
(\mathrm{g} /(\mathrm{L} \cdot \mathrm{h}))\end{array}$ & $\begin{array}{c}\text { Residual } \\
\text { Inhibitor } \\
\quad(\%)\end{array}$ \\
\hline \multirow{5}{*}{ Furfural } & 0 & $9.58 \pm 0.456$ & $0.804 \pm 0.022$ & $<0.1$ & $19.0 \pm 1.76$ & $0.70 \pm 0.01$ & $<0.1$ & $0.850 \pm 0.013$ & $2.38 \pm 0.120$ & $4.02 \pm 0.013$ & 0.0 \\
\hline & 2 & $9.78 \pm 0.903$ & $0.565 \pm 0.021$ & $<0.1$ & $20.0 \pm 0.67$ & $1.85 \pm 0.12$ & $<0.1$ & $0.968 \pm 0.005$ & $2.04 \pm 0.188$ & $3.64 \pm 0.065$ & 0.0 \\
\hline & 3 & $8.2 \pm 0.312$ & $0.430 \pm 0.010$ & $<0.1$ & $22.3 \pm 1.11$ & $2.45 \pm 0.12$ & $<0.1$ & $1.04 \pm 0.008$ & $1.85 \pm 0.356$ & $3.44 \pm 0.096$ & 0.0 \\
\hline & 4 & $4.78 \pm 0.785$ & $0.333 \pm 0.013$ & $<0.1$ & $22.1 \pm 0.85$ & $1.94 \pm 0.88$ & $<0.1$ & $0.956 \pm 0.005$ & $1.46 \pm 0.256$ & $2.16 \pm 0.153$ & 0.0 \\
\hline & 5 & $2.1 \pm 0.411$ & $0.240 \pm 0.016$ & $6.14 \pm 0.88$ & $15.9 \pm 0.34$ & $1.38 \pm 0.03$ & $<0.1$ & $0.973 \pm 0.003$ & $0.398 \pm 0.365$ & $3.31 \pm 0.245$ & 0.0 \\
\hline \multirow{5}{*}{$\begin{array}{l}\text { Hydroxy } \\
\text { Methyl } \\
\text { Furfural } \\
\text { (HMF) }\end{array}$} & 1 & $9.96 \pm 0.188$ & $0.739 \pm 0.091$ & $<0.1$ & $19.5 \pm 0.29$ & $1.23 \pm 0.009$ & $<0.1$ & $0.975 \pm 0.012$ & $2.44 \pm 0.122$ & $3.81 \pm 0.210$ & 0.0 \\
\hline & 2 & $9.44 \pm 0.442$ & $0.521 \pm 0.072$ & $<0.1$ & $19.5 \pm 0.83$ & $1.35 \pm 0.11$ & $<0.1$ & $0.962 \pm 0.011$ & $1.95 \pm 0.061$ & $3.91 \pm 0.102$ & 0.0 \\
\hline & 3 & $8.52 \pm 0.226$ & $0.467 \pm 0.012$ & $<0.1$ & $20.0 \pm 1.18$ & $2.06 \pm 0.15$ & $<0.1$ & $0.992 \pm 0.016$ & $1.66 \pm 0.091$ & $3.13 \pm 0.131$ & 0.0 \\
\hline & 4 & $6.24 \pm 0.243$ & $0.484 \pm 0.017$ & $<0.1$ & $20.0 \pm 0.89$ & $1.48 \pm 0.08$ & $<0.1$ & $0.987 \pm 0.006$ & $1.17 \pm 0.026$ & $2.65 \pm 0.214$ & 0.0 \\
\hline & 5 & $6.36 \pm 0.358$ & $0.306 \pm 0.022$ & $<0.1$ & $20.1 \pm 0.79$ & $3.15 \pm 0.03$ & $<0.1$ & $0.984 \pm 0.007$ & $1.11 \pm 0.110$ & $2.08 \pm 0.256$ & 0.0 \\
\hline
\end{tabular}

$\mathrm{OD}_{562 \mathrm{~nm}}$, optical density of cell growth at $562 \mathrm{~nm} ; \mu_{\max }$, specific growth rate; LA, Lactic acid.

Table 3. Effect of carboxylic acid on lactic acid fermentation efficiency by Bacillus coagulans Azu-10.

\begin{tabular}{|c|c|c|c|c|c|c|c|c|c|c|c|}
\hline $\begin{array}{l}\text { Carboxylic } \\
\text { Acids }\end{array}$ & $\begin{array}{c}\text { Inhibition } \\
(\mathrm{g} / \mathrm{L})\end{array}$ & $\begin{array}{c}\text { Max. } \\
\text { Biomass } \\
\left(\mathrm{OD}_{562 \mathrm{~nm}}\right)\end{array}$ & $\begin{array}{l}\mu_{\max } \\
\left(\mathrm{h}^{-1}\right)\end{array}$ & $\begin{array}{c}\text { Residual } \\
\text { Xylose (g/L) }\end{array}$ & $\begin{array}{c}\text { LA } \\
(\mathrm{g} / \mathrm{L})\end{array}$ & $\begin{array}{l}\text { Acetic Acid } \\
(\mathrm{g} / \mathrm{L})\end{array}$ & $\begin{array}{c}\text { Ethanol } \\
(\mathrm{g} / \mathrm{L})\end{array}$ & $\begin{array}{c}\text { LA Yield } \\
\text { (g/g) }\end{array}$ & $\begin{array}{c}\text { LA } \\
\text { Productivity } \\
(\mathrm{g} /(\mathrm{L} \cdot \mathrm{h}))\end{array}$ & $\begin{array}{c}\text { Max. LA } \\
\text { Productivity } \\
\text { (g/(L·h)) }\end{array}$ & $\begin{array}{c}\text { Residual } \\
\text { Inhibitor } \\
\quad(\%)\end{array}$ \\
\hline \multirow{4}{*}{ Acetic acid } & 5 & $8.46 \pm 0.302$ & $0.401 \pm 0.021$ & $<0.1$ & $20.5 \pm 1.12$ & $0.60 \pm 0.16$ & $<0.1$ & $1.05 \pm 0.041$ & $2.05 \pm 0.065$ & $3.81 \pm 0.141$ & 100 \\
\hline & 10 & $8.64+0.611$ & $0.446+0.036$ & $<0.1$ & $18.4+1.33$ & $0.42 \pm 0.08$ & $<0.1$ & $1.0 \pm 0.063$ & $1.96+0.120$ & $4.32 \pm 0.215$ & 100 \\
\hline & 15 & $6.34 \pm 0.223$ & $0.454 \pm 0.006$ & $<0.1$ & $20.0 \pm 0.99$ & $1.76 \pm 0.11$ & $<0.1$ & $1.01 \pm 0.032$ & $1.04 \pm 0.012$ & $1.40 \pm 0.161$ & 100 \\
\hline & 20 & $0.32 \pm 0.005$ & $0.030 \pm 0.009$ & $<0.1$ & $\begin{array}{c}20.0+0.99 \\
-\end{array}$ & $1.70+0.11$ & $<0.1$ & $\begin{array}{c}1.01 \pm 0.002 \\
-\end{array}$ & $\begin{array}{c}1.07 \pm 0.012 \\
-\end{array}$ & $\begin{array}{c}1.70 \perp 0.101 \\
-\end{array}$ & 100 \\
\hline \multirow[b]{2}{*}{ Formic acid } & 5 & $5.3 \pm 0.405$ & $0.481 \pm 0.008$ & $<0.1$ & $19.2 \pm 0.85$ & $1.13 \pm 0.04$ & $<0.1$ & $0.991 \pm 0.021$ & $0.963 \pm 0.032$ & $2.47 \pm 0.099$ & 100 \\
\hline & 10 & $0.42 \pm 0.012$ & $0.189 \pm 0.012$ & $18.85 \pm 1.34$ & $0.616 \pm 0.15$ & $0.08 \pm 0.01$ & $<0.1$ & 0 & 0 & 0 & 100 \\
\hline \multirow{6}{*}{$\begin{array}{l}\text { Levulinic } \\
\text { acid }\end{array}$} & 1 & $8.3 \pm 0.215$ & $0.693 \pm 0.025$ & $<0.1$ & $19.7 \pm 1.32$ & $1.05 \pm 0.23$ & $<0.1$ & $1.01 \pm 0.012$ & $2.47 \pm 0.025$ & $4.17 \pm 0.102$ & 98.8 \\
\hline & 2 & $7.08 \pm 0.561$ & $0.508 \pm 0.035$ & $<0.1$ & $19.5 \pm 1.17$ & $1.87 \pm 0.44$ & $<0.1$ & $1.00 \pm 0.021$ & $2.47 \pm 0.017$ & $4.79 \pm 0.135$ & 94.1 \\
\hline & 3 & $8.6 \pm 0.421$ & $0.626 \pm 0.017$ & $<0.1$ & $18.1 \pm 1.55$ & $0.99 \pm 0.15$ & $<0.1$ & $0.915 \pm 0.005$ & $2.26 \pm 0.020$ & $4.33 \pm 0.120$ & 98.7 \\
\hline & 4 & $7.18 \pm 0.892$ & $0.575 \pm 0.032$ & $<0.1$ & $19.6 \pm 1.19$ & $0.90 \pm 0.12$ & $<0.1$ & $0.955 \pm 0.004$ & $2.45 \pm 0.023$ & $4.76 \pm 0.142$ & 94.3 \\
\hline & 5 & $8.44 \pm 0.883$ & $0.541 \pm 0.043$ & $<0.1$ & $20.2 \pm 1.14$ & $0.438 \pm 0.07$ & $<0.1$ & $1.01 \pm 0.052$ & $2.47 \pm 0.024$ & $4.12 \pm 0.097$ & 98.8 \\
\hline & 7 & $9.12 \pm 0.604$ & $0.466 \pm 0.035$ & $<0.1$ & $19.5 \pm 1.31$ & $0.69 \pm 0.02$ & $<0.1$ & $1.00 \pm 0.019$ & $1.95 \pm 0.036$ & $3.76 \pm 0.081$ & 91.6 \\
\hline
\end{tabular}

$\mathrm{OD}_{562 \mathrm{~nm}}$, optical density of cell growth at $562 \mathrm{~nm} ; \mu_{\max }$, specific growth rate; LA, Lactic acid. 

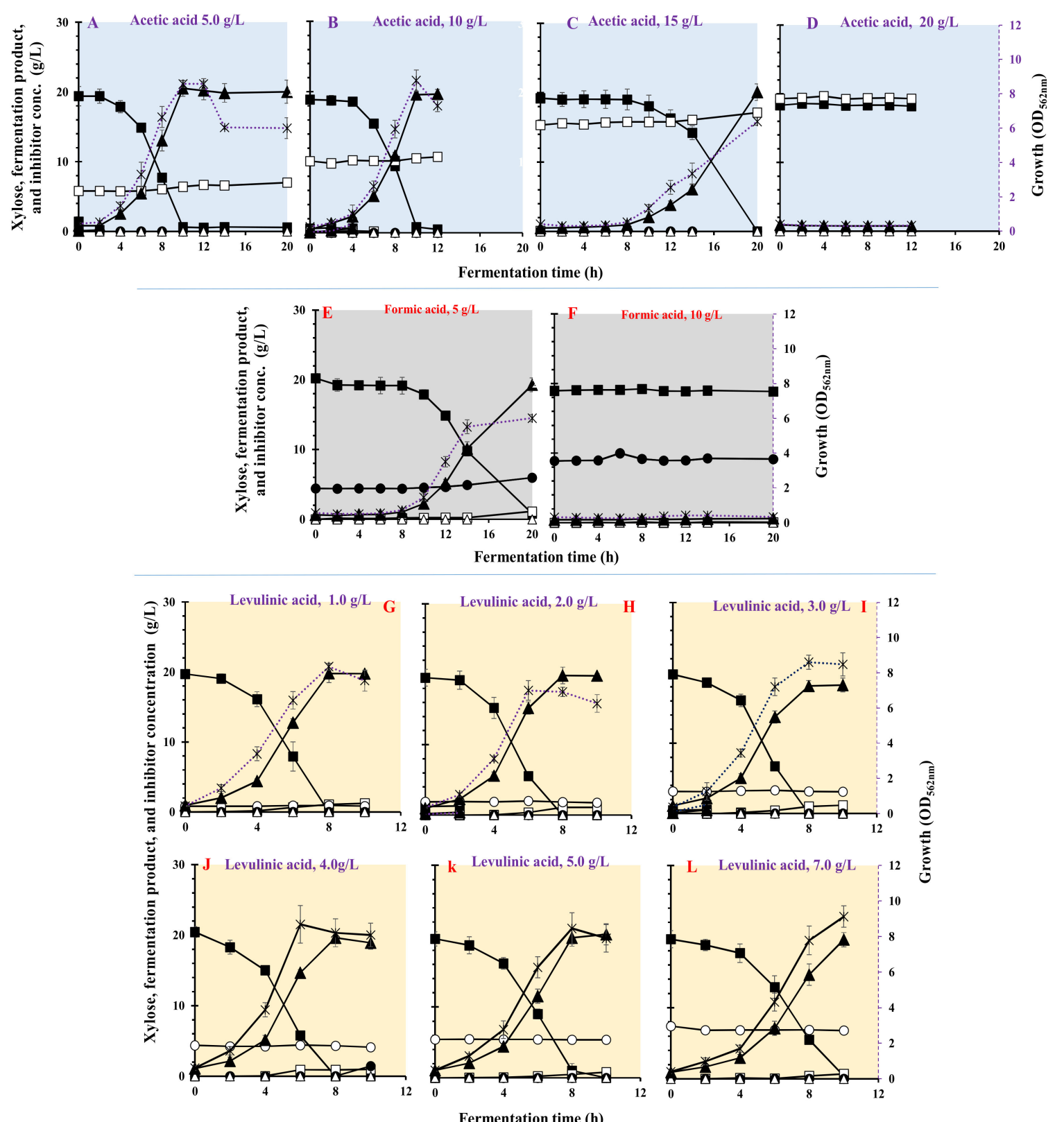

Figure 2. Effect of different concentrations of acetic acid (A-D), formic acid (E,F), and levulinic acid (G-L) on the growth and lactic acid production by Bacillus coagulans Azu-10. Symbols: $\mathbf{\square}$, xylose (g/L); $\square$, acetic acid (g/L); $\bigcirc$, inhibitor (Acetic acid, formic acid, or levulinic acid, g/L); • , formic acid (g/L); $\Delta$, ethanol (g/L); $\mathbf{\Lambda}$, lactic acid (g/L); ${ }^{*}$, growth $\left(\mathrm{OD}_{562 \mathrm{~nm}}\right)$. The standard deviation is less than the size of symbols if no error bars are seen.

\subsection{Effect of Phenolic Compounds on Growth and LA Fermentation}

The effect of different phenolic compounds (phenolic ketone, phenolic acids, and phenolic aldehydes) on LA fermentation by Azu-10 is shown in Figure 3 and Table 4 . $p$-coumaric acid at $1.0 \mathrm{~g} / \mathrm{L}$ negatively affected growth that was $\mathrm{OD}_{562}$ of 2.36 at a specific growth rate of $0.313 \mathrm{~h}^{-1}$. The strain could not completely utilize xylose after $20 \mathrm{~h}$ of fermentation where the residual xylose was $5.33 \mathrm{~g} / \mathrm{L}$ (Figure $3 \mathrm{~A}$ ). Lactic acid was produced at $15.6 \mathrm{~g} / \mathrm{L}$ with LA yield of 1.03 , LA productivity of $0.782 \mathrm{~g} /(\mathrm{L} \cdot \mathrm{h})$, and maximum LA productivity at $1.185 \mathrm{~g} /(\mathrm{L} \cdot \mathrm{h})$. Low acetic acid was produced at $0.40 \mathrm{~g} / \mathrm{L}$, and no ethanol or formic acid were detected. The strain Azu-10 showed high stability to $p$-coumaric 
acid but not detoxification, as appeared from the $98 \%$ residual $p$-coumaric acid at the end of fermentation.
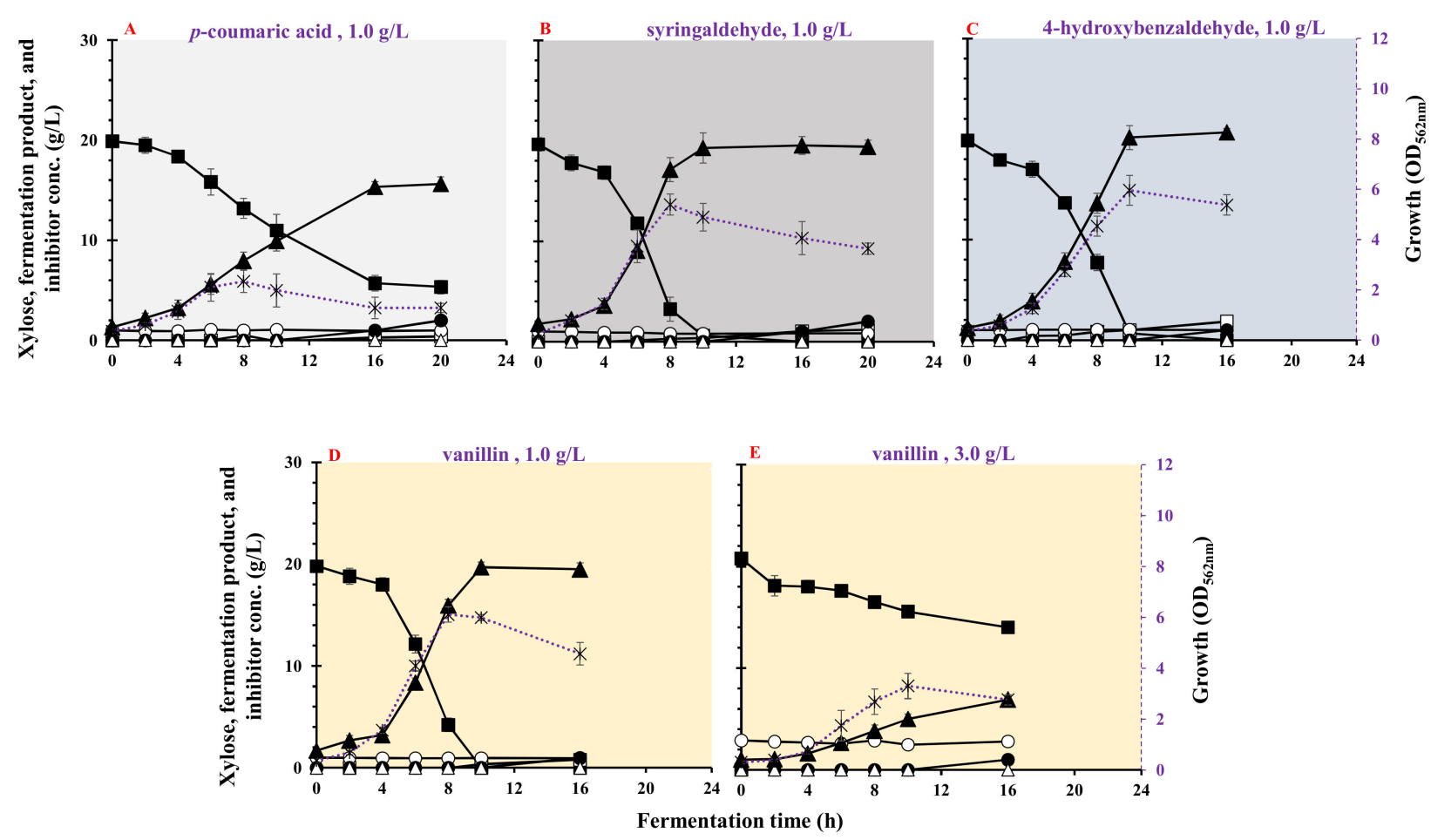

Figure 3. Effect of $1.0 \mathrm{~g} / \mathrm{L}$ of $p$-coumaric acid (A), syringaldehyde (B), 4-hydroxybenzaldehyde (C), and 1.0-3.0 g/L vanillin (D,E) on the growth and lactic acid production by Bacillus coagulans Azu-10. Symbols: $\mathbf{\square}$, xylose (g/L); $\square$, acetic acid (g/L); $\mathrm{O}$, inhibitor $(\mathrm{g} / \mathrm{L}) ; \bullet$, formic acid $(\mathrm{g} / \mathrm{L}) ; \Delta$, ethanol $(\mathrm{g} / \mathrm{L}) ; \mathbf{\Lambda}$, lactic acid $(\mathrm{g} / \mathrm{L}){ }^{*}$, growth $\left(\mathrm{OD}_{562 \mathrm{~nm}}\right)$. The standard deviation is less than the size of symbols if no error bars are seen.

Table 4. Effect of phenolic compounds on lactic acid fermentation efficiency by Bacillus coagulans Azu-10.

\begin{tabular}{|c|c|c|c|c|c|c|c|c|c|c|c|}
\hline Phenols & $\begin{array}{c}\text { Inhibitors } \\
(\mathrm{g} / \mathrm{L})\end{array}$ & $\begin{array}{c}\text { Max. } \\
\text { Biomass } \\
\left(\mathrm{OD}_{562 \mathrm{~nm}}\right)\end{array}$ & $\begin{array}{l}\mu_{\max } \\
\left(h^{-1}\right)\end{array}$ & $\begin{array}{c}\text { Residual } \\
\text { Xylose } \\
\text { (g/L) }\end{array}$ & $\begin{array}{c}\mathrm{LA} \\
(\mathrm{g} / \mathrm{L})\end{array}$ & $\begin{array}{c}\text { Acetic Acid } \\
(\mathrm{g} / \mathrm{L})\end{array}$ & $\begin{array}{l}\text { Ethanol } \\
(\mathrm{g} / \mathrm{L})\end{array}$ & $\underset{(\mathrm{g} / \mathrm{g})}{\text { LA Yield }}$ & $\underset{\substack{\text { LA } \\
\text { Productivity } \\
(\mathrm{g} /(\mathrm{L} \cdot \mathrm{h}))}}{ }$ & $\begin{array}{c}\text { Max. LA } \\
\text { Productivity } \\
(\mathrm{g} /(\mathrm{L} \cdot \mathrm{h}))\end{array}$ & $\begin{array}{c}\text { Residual } \\
\text { Inhibitor } \\
(\%)\end{array}$ \\
\hline $\begin{array}{l}p \text {-coumaric acid } \\
\text { Syringaldehyde }\end{array}$ & $\begin{array}{l}1.0 \\
1.0\end{array}$ & $\begin{array}{l}2.36 \pm 0.442 \\
4.96 \pm 0.554\end{array}$ & $\begin{array}{l}0.313 \pm 0.012 \\
0.482 \pm 0.056\end{array}$ & $\begin{array}{c}5.33 \pm 0.67 \\
<0.1\end{array}$ & $\begin{array}{l}15.6 \pm 0.94 \\
19.2 \pm 0.88\end{array}$ & $\begin{array}{l}0.40 \pm 0.02 \\
0.36 \pm 0.01\end{array}$ & $\begin{array}{l}<0.1 \\
<0.1\end{array}$ & $\begin{array}{c}1.01 \pm 0.021 \\
0.991 \pm 0.032\end{array}$ & $\begin{array}{c}0.782 \pm 0.111 \\
1.92 \pm 0.069\end{array}$ & $\begin{array}{l}1.18 \pm 0.105 \\
4.04 \pm 0.026\end{array}$ & $\begin{array}{l}98.0 \\
82.0\end{array}$ \\
\hline $\begin{array}{c}p- \\
\text { hydroxybenzaldhyde }\end{array}$ & 1.0 & $5.96 \pm 0.602$ & $0.388 \pm 0.053$ & $<0.1$ & $20.1 \pm 0.49$ & $1.02 \pm 0.35$ & $<0.1$ & $1.00 \pm 0.010$ & $2.01 \pm 0.06$ & $3.26 \pm 0.183$ & 100 \\
\hline Vanillin & $\begin{array}{l}1.0 \\
3.0\end{array}$ & $\begin{array}{c}6.02 \pm 0.321 \\
3.3 \pm 0.531\end{array}$ & $\begin{array}{l}0.497 \pm 0.011 \\
0.441 \pm 0.021\end{array}$ & $\begin{array}{c}<0.1 \\
13.9 \pm 0.59\end{array}$ & $\begin{array}{c}19.6 \\
7.1\end{array}$ & $\begin{array}{c}0.36 \pm 0.01 \\
\quad<0.06\end{array}$ & $\begin{array}{l}<0.1 \\
<0.1\end{array}$ & $\begin{array}{l}0.98 \pm 0.016 \\
1.01 \pm 0.020\end{array}$ & $\begin{array}{c}1.96 \pm 0.035 \\
0.432 \pm 0.015\end{array}$ & $\begin{array}{c}3.79 \pm 0.187 \\
0.524 \pm 0.009\end{array}$ & $\begin{array}{l}94.0 \\
97.2\end{array}$ \\
\hline
\end{tabular}

$\mathrm{OD}_{562 \mathrm{~nm}}$, optical density of cell growth at $562 \mathrm{~nm} ; \mu_{\max }$, specific growth rate; LA, Lactic acid.

On the other hand, strain Azu-10 exhibited higher biomass at $\mathrm{OD}_{562} 4.96$ and 5.96 with a high specific growth rate of 0.482 and $0.388 \mathrm{~h}^{-1}$ in the presence of $1.0 \mathrm{~g} / \mathrm{L}$ of syringaldehyde or $p$-hydroxybenzaldehyde, respectively. Xylose was completely consumed within $10 \mathrm{~h}$ with the production of 19.2-20.1 g/L LA (Figure 3B,C) at yield 0.99-1.03 g/g, the productivity of $1.92-2.01 \mathrm{~g} /(\mathrm{L} \cdot \mathrm{h})$, and maximal productivities of $3.26-4.04 \mathrm{~g} /(\mathrm{L} \cdot \mathrm{h})$. No production of ethanol or formic acid was detected with the formation of little acetic acid at $0.36-1.02 \mathrm{~g} / \mathrm{L}$. For syringaldehyde, $82 \%$ was left in the fermentation media, while $100 \%$ of $p$-hydroxybenzaldehyde was left at the end of fermentation.

Similarly, vanillin at $1.0 \mathrm{~g} / \mathrm{L}$ did not inhibit fermentation by Azu-10 (Figure 3D), as indicated by high biomass at $\mathrm{OD}_{562}$ of 6.02 with a specific growth rate at $0.497 \mathrm{~h}^{-1}$, where complete consumption of xylose was achieved within $10 \mathrm{~h}$ with LA production of $19.6 \mathrm{~g} / \mathrm{L}$ at a yield of $0.99 \mathrm{~g} / \mathrm{g}$, the productivity of $1.96 \mathrm{~g} /(\mathrm{L} \cdot \mathrm{h})$, and maximal productivity of $3.79 \mathrm{~g} /(\mathrm{L} \cdot \mathrm{h})$. Acetic acid as a by-product was detected at $0.36 \mathrm{~g} / \mathrm{L}$, without production of ethanol or formic acid. Vanillin was left at the end of fermentation at $94.0 \%$ of the original 
load. On the other hand, although high biomass $\left(\mathrm{OD}_{562}=3.3\right)$ with a specific growth rate $\left(0.441 \mathrm{~h}^{-1}\right)$ was achieved by Azu-10 in the presence of $3.0 \mathrm{~g} / \mathrm{L}$ vanillin, only $7.1 \mathrm{~g} / \mathrm{L}$ of lactic acid at low productivity of $0.430 \mathrm{~g} /(\mathrm{L} \cdot \mathrm{h})$ was produced without by-products' formation (Figure 3E).

\section{Discussion}

Biotechnological conversion of lignocellulosic biomass feedstock to LA via a sugarplatform process should mostly involve a thermochemical pretreatment step [3]. However, one of the most important drawbacks of such pretreatments is the formation of inhibitory by-products that might inhibit further enzymatic saccharifications or microbial growth and consequently compromise the effective LA fermentation process [2]. The hemicellulosic hydrolysate contains pentose sugar (mainly xylose) that is not utilized by most LA-producing bacteria; however, pentose utilization follows the heterofermentative pattern that produces low LA yield with excess by-products' formation [16]. Besides, mesophilic fermentations limit the effective LA production due to the unavailability of most LA producers to simulate the saccharification and fermentation (SSF) process and the contamination problems that occurred [14]. Therefore, expanding the global production of lignocellulosic LA requires potential thermophilic producers with increasing resistance to pre-treatment process inhibitors. Hence, this study was conducted to obtain effective thermophilic xylose-utilizing LA-producers and to evaluate the effect of various groups of lignocellulosic-inhibitory by-products on its growth and LA fermentation efficiency.

In this study, isolate Azu-10 was obtained from a soil sample and selected as a homofermentative xylose-utilizing LA producer based on the screening protocol on xylosecontaining media supplemented with furan and acetic acid as the most common byproducts of lignocellulose hydrolysates. This strain is Gram-positive, rod-shaped, and identified as Bacillus coagulans Azu-10 according to API-50 CHL sugar fermentation pattern and $16 \mathrm{~S}$ rRNA gene sequence.

Xylose-fermenting bacteria metabolize it by its conversion into xylulose-5-phosphate that is further metabolized homofermentative through the pentose phosphate pathway (PPP) and Embden-Meyerhof pathway (EMP) (theoretical value of xylose conversion is $1.0 \mathrm{~g} / \mathrm{g}$ ) or heterofermentative through the phosphoketolase pathway (theoretical value of xylose conversion is $0.6 \mathrm{~g} / \mathrm{g}$ ) [12,17]. Since the conversion of xylose to lactic acid in our study was close to $1.0 \mathrm{~g} / \mathrm{g}$, this result implies that Bacillus coagulans Azu-10 could metabolize xylose into only lactic acid by the homofermentative pathway through the PPP [17]. Besides, fermentative LA production by Bacillus spp. is usually preferred over other producers (Lactic acid bacteria or Rhizopus sp.) due to their higher growth rates, tolerance to high temperatures, requirements of simple nutritional conditions or even mineral salt medium containing low-nitrogen sources, facultative anaerobic nature, and the ability to homoferment a wide range of pentoses and hexoses contained in lignocellulosic materials [12,18].

The $\mathrm{pH}$ value of the fermentation media is one of the most important key parameters for effective LA fermentation. Both $\mathrm{pH}$-uncontrolled and $\mathrm{pH}$-controlled fermentation by strain Azu-10 at $\mathrm{pH} 5.0$ and $\mathrm{pH}$ 7.5-9.0 have resulted in low biomass of $\mathrm{OD}_{562}$ ranging 0.180-3.14, as compared with controlled $\mathrm{pH}$ fermentations at 5.5-7.0 that ranged $\mathrm{OD}_{562}$ of 4.54-9.42. Consequently, better LA fermentations were achieved in the slightly acidic and neutral conditions ( $\mathrm{pH}$ 5.5-7.0) with an optimal $\mathrm{pH}$ value of 7.0. The optimal $\mathrm{pH}$ of the most reported LA-producing Bacillus spp. for growth and LA fermentation is at neutral conditions and those species are sensitive to acidic $\mathrm{pH}$ [18]. The value of $\mathrm{pH}$ between 6.0 and 6.5 was optimal for LA production from glucose by Bacillus coagulans WCP10-4 [19]. On the other hand, Bacillus sp. WL-S20 showed tolerance up to $\mathrm{pH} 10.0$ [20], and Bacillus acidicola tolerated $\mathrm{pH}$ values up to 3.5 [21]. The decreased growth and fermentation efficiency at low $\mathrm{pH}$ might be attributed to the un-dissociated forms of acids which can cross the cell membrane resulting in a decrease of the intracellular $\mathrm{pH}$ and injury of the cellular functions as the energy is mainly consumed to maintain the $\mathrm{pH}$ gradient instead of 
cell growth [22,23]. Thus, controlling the $\mathrm{pH}$ values at neutral conditions by addition of $\mathrm{NaOH}$ as a neutralizing agent relieves this problem and results in sustained cell growth and increases LA concentrations.

In this study, Bacillus coagulans Azu-10 exhibited efficient LA production up to $50-55{ }^{\circ} \mathrm{C}$ with complete consumption of sugars and homofermentative LA production. This thermophilic nature should add several advantages compared with mesophilic fermentations, including saving energy, facilitating open fermentation, minimizing contamination risk, providing the capability for efficient SSF processes, and lowering the overall process cost [14]. Several thermophilic LA-producing Bacillus spp. have been reported that showed optimal growth temperatures between 45 and $60{ }^{\circ} \mathrm{C}$ with limited growth up to $70^{\circ} \mathrm{C}$. Bacillus sp. MC-07 was isolated from compost and produced LA from starch at $50{ }^{\circ} \mathrm{C}$ [18]. Bacillus coagulans JI12 produced LA from xylose at $50{ }^{\circ} \mathrm{C}$ [24]. A thermophilic Bacillus coagulans 36D1 showed better LA production performance than mesophilic Lactococcus lactis subsp. lactis NRRL B-4449 by SSF of crystalline cellulose [25].

Lignocellulose is an interesting renewable substrate that can be used as feedstock for LA fermentation processes. However, direct utilization of this biomass by LA-producers is rarely reported $[13,26]$; therefore, most studies reported that pretreatment is required to depolymerize lignocellulose into fermentable monomeric sugars for high LA production [27]. Although thermochemical pretreatment increases the accessibility of lignocellulosic sugars, a wide range of inhibitors or lignocellulose-degradation products are usually generated [28] that might drastically affect the enzymatic hydrolysis and fermentation process $[29,30]$. The type and quantity of the released inhibitors are mainly related to the biomass composition and the utilized pretreatment method [31]. On the other hand, the degree of toxicity varies greatly with the microbial species [28,32]. Thus, it is necessary to investigate the toxicity of various lignocellulosic-derived inhibitors on the LA fermentation efficiency by strain Azu-10 to either optimize the pretreatment methods or to develop effective detoxification methods for increased biorefinery of specific biomass to LA.

Compounds of 2-furaldehyde (furfural) and 5-hydroxymethyl furfural (HMF) are formed when pentoses and hexoses are exposed to thermal oxidation in acidic conditions, respectively [33]. Formic acid and levulinic acid are formed by subsequent degradation of furfural and HMF, respectively. Acetic acid and formic acid can be formed by the oxidation of sugars during alkaline pretreatment [34]. Phenolic compounds are formed as a result of lignin degradation or when the cross-links between hemicellulose and lignin are broken [27]. Furfural and HMF have existed in lignocellulosic hydrolysate at concentrations ranging between 0 and $5 \mathrm{~g} / \mathrm{L}$ for each compound [35]. Acetic acid is usually found at the highest concentration of carboxylic acid at concentrations ranging from 1.0-10 g/L, while formic acid is present in lower concentrations (commonly a tenth of acetic acid concentrations), and other weak acids are present at a lower concentration than formic acid [35]. On the other hand, the concentration levels ranging $0.5-2.0 \mathrm{~g} / \mathrm{L}$ have been frequently used as the reference values to evaluate the effect of various lignin degradation products on xylose fermentation [36].

In this study, the effects of various concentrations of representative inhibitory compounds, such as furan derivatives, weak acids, and phenolics, were evaluated on the growth performance and LA production by strain Azu-10. The strain of Azu-10 exhibited high biomass $\left(\mathrm{OD}_{562}\right.$ values) and LA fermentation with complete consumption of xylose in the presence of 1.0-4.0 g/L furfural and 1.0-5.0 g/L of HMF. HMF showed lower toxicity on LA fermentation as compared with furfural. Besides, this strain could efficiently metabolize and detoxify furfural/HMF compounds up to 5.0 g/L. Furthermore, strain Azu 10 was stable under all the tested carboxylic acids. It showed relatively high LA fermentation in the presence of 5.0-15.0 g/L acetic acid. On the other hand, it could grow effectively in the presence of various concentrations of levulinic acid up to $7.0 \mathrm{~g} / \mathrm{L}$, but it could not tolerate higher than $5 \mathrm{~g} / \mathrm{L}$ of formic acid. For phenolic compounds (phenolic ketone, phenolic acids, and phenolic aldehydes) derived from lignin, $p$-coumaric acid was the most 
toxic form, which inhibited LA fermentation efficiency by Azu-10 at $1.0 \mathrm{~g} / \mathrm{L}$, contrary to syringaldehyde or $p$-hydroxybenzaldehyde, and vanillin at the same concentration.

Furfural and HMF were reported to be highly toxic at $0.5-1 \mathrm{~g} / \mathrm{L}$, while formic and acetic acids at less than $4 \mathrm{~g} / \mathrm{L}$, levulinic acid at $10 \mathrm{~g} / \mathrm{L}$, and $p$-coumaric acids were not toxic in batch fermentation by Rhizopus oryzae [9]. The toxicity of furfural was directly related to the formation of reactive oxygen species (ROS); besides, high temperature accelerates the formation of ROS [37]. Bacillus coagulans showed less growth-inhibition by 5-HMF than furfural [8]. Formic acid (Pka 3.75) was also previously reported as the major inhibitor of the studied weak acids $[9,38]$. The reduced growth rate in the presence of weak acids (acetic acid (Pka, 4.25), formic acid (Pka, 3.75), and levulinic acid (Pka, 4.66)) [39] can be attributed to their dissociation upon entering the cell and consequently lead to an increase in cell intracellular $\mathrm{pH}$ and thus cells export protons at the expense of ATP to restore intracellular $\mathrm{pH}$ [38]. Formic acid may be inhibitorier than acetic or levulinic acid as the PKa value of formic acid is lowered and thus the amount of undissociated formic acid is lowered at the same $\mathrm{pH}$. Besides, formic acid has a smaller size than acetic and levulinic acids, facilitating its better diffusion across the cell membrane causing higher anion toxicity $[38,40]$. Acetic acid has previously been described as only a minor growth inhibitor for Bacillus coagulans [41]. Levulinic acid (at $7.0 \mathrm{~g} / \mathrm{L}$ ) was found to be slightly more of an inhibitor than acetic acid as it gives the decreased fermentation kinetics at $5.0 \mathrm{~g} / \mathrm{L}$ (maximum LA productivities are 3.76 and $3.81 \mathrm{~g} /(\mathrm{L} \cdot \mathrm{h}$ ), respectively). This might be due to the greater lipophilicity of levulinic acid [38,40]. van der Pol et al. [8] reported that Lactobacillus casei DSM 20011, Lactobacillus delbrueckii DSM 20073, Lactococcus lactis DSM 20481, Bacillus coagulans DSM 2314, and Bacillus smithii DSM 4216 show significant inhibition of growth at formic acid concentrations of $7.5 \mathrm{~g} / \mathrm{L}$. Levulinic acid at a concentration of $10 \mathrm{~g} / \mathrm{L}$ exhibited the least inhibitory action among 12 different inhibitory compounds, where only the growth of Bacillus smithii was significantly inhibited [8]. Compared to the control without any inhibitor, cell growth and lactic acid fermentation efficiency were significantly decreased in the presence of phenolic compounds at $1.0 \mathrm{~g} / \mathrm{L}$ (Table 4). The decrease in lactic acid production was obvious by $p$-coumaric acid, while syringaldehyde, 4-hydroxybenzaldehyde, and vanillin showed moderate toxicity on cell growth but not on LA fermentation efficiency. A sharp decrease in acetic acid production was observed with phenolic compounds as compared with other inhibitory compounds. This might be attributed to the similar structure of syringaldehyde, vanillin, and 4-hydroxybenzaldehyde [8]. It was reported that most of the pretreated lignocellulosic biomasses contained phenolic aldehydes with a concentration lower than $0.2 \mathrm{~g} / \mathrm{L}$ and high p-coumaric acid concentration up to $0.75 \mathrm{~g} / \mathrm{L}$ [31,42]. Strain Lb. delbrueckii DSM 20073 shows significant inhibition towards vanillin and 4-hydroxybenzaldehyde at $0.5 \mathrm{~g} / \mathrm{L}$, and towards furans at concentrations exceeding $1.0 \mathrm{~g} / \mathrm{L}$ [5]. The inhibitory concentration of lignocellulose-derived inhibitors for growth is considered strain and or condition-specific. Lb. delbrueckii was significantly inhibited by vanillin $(0.75 \mathrm{~g} / \mathrm{L})$, while $L b$. lactis showed growth at vanillin concentrations of $2.5 \mathrm{~g} / \mathrm{L}$. Also, $p$-coumaric acid significantly inhibited the growth of most LA-producing microorganisms in concentrations above $1.0 \mathrm{~g} / \mathrm{L}$ [8]. Our reported strain showed high tolerance to furans up to $5.0 \mathrm{~g} / \mathrm{L}$. In contrast to mesophilic strains, thermotolerant strains such as Bacillus coagulans and Bacillus smithii (grown at $50{ }^{\circ} \mathrm{C}$ ) or $\mathrm{Lb}$. delbrueckii (grown at $45^{\circ} \mathrm{C}$ ) showed stronger growth inhibition in the presence of furans.

\section{Conclusions}

A new Bacillus coagulans Az-10 strain has been obtained and characterized with the potential to be used as a production platform for homofermentative LA production. Besides, this strain would facilitate SSF and open fermentation as it exhibited an optimal LA fermentation at $50{ }^{\circ} \mathrm{C}$. Moreover, strain Azu-10 was able to detoxify furan inhibitors (furfural and HMF up to $5.0 \mathrm{~g} / \mathrm{L}$ ) and could tolerate most of the lignocellulose-derived key inhibitors, including furans, weak acids, and phenolic compounds, at higher concentrations 
with high biomass and LA-fermentation capability in terms of high LA production titer, yield, and productivity. The utilization of xylose and its assimilation via PPP-pathway by strain Azu-10 would further reduce the production cost and improve the techno-economic feasibility of lactic acid production from cellulosic-substrates. Therefore, the present study provides a vital candidate for efficient LA production from second-generation lignocellulosic materials.

Supplementary Materials: The following are available online at https://www.mdpi.com/2311-5 637/7/1/17/s1, Figure S1: Phylogenetic tree for isolate Azu-10 based on 16S rRNA gene sequence, Table S1: Results of API-50 CHL sugar fermentation pattern for isolate Azu-10 after incubation for $48 \mathrm{~h}$ at $50^{\circ} \mathrm{C}$, Table S2: Effect of $\mathrm{pH}$ value on lactic acid fermentation efficiency by B. coagulans Azu-10.

Author Contributions: M.A.A.-R.: Conceptualization, Formal analysis, Investigation, Methodology, Writing-original draft, review and editing; S.E.-D.H.: Formal analysis, Investigation, Methodology, Writing-review and editing; A.F.: Conceptualization, Formal analysis, Investigation, Methodology, Writing-review and editing; A.A.R.: Conceptualization, Formal analysis, Investigation, Methodology, Writing—review and editing; M.G.B.: Conceptualization, Investigation, Methodology, Writing-review and editing; S.G.D.: Investigation, Methodology, Writing—review and editing. All authors have read and agreed to the published version of the manuscript.

Funding: This work was not supported by any funding.

Institutional Review Board Statement: Not applicable.

Informed Consent Statement: Not applicable.

Data Availability Statement: The data used to support the findings of this study are available from the corresponding author upon request.

Conflicts of Interest: The authors declare no conflict of interest.

\section{References}

1. Abedi, E.; Hashemi, S.M.B. Lactic acid production—Producing microorganisms and substrates sources-state of art. Heliyon 2020, 6, 04974. [CrossRef] [PubMed]

2. Abdel-Rahman, M.A.; Tashiro, Y.; Sonomoto, K. Lactic acid production from lignocellulose- derived sugars using lactic acid bacteria: Overview and limits. J. Biotechnol. 2011, 156, 286-301. [CrossRef] [PubMed]

3. Cubas-Cano, E.; González-Fernández, C.; Ballesteros, M.; Tomás-Pejó, E. Biotechnological advances in lactic acid production by lactic acid bacteria: Lignocellulose as novel substrate. Biofuel Bioprod. Biorefin. 2018, 12, 290-303. [CrossRef]

4. Abdel-Rahman, M.A.; Sonomoto, K. Opportunities to overcome the current limitations and challenges for efficient microbial production of optically pure lactic acid. J. Biotechnol. 2016, 236, 176-192. [CrossRef] [PubMed]

5. Saini, R.; Osorio-Gonzalez, C.S.; Hegde, K.; Brar, S.K.; Magdouli, S.; Vezina, P.; Avalos-Ramirez, A. Lignocellulosic Biomass-Based Biorefinery: An Insight into Commercialization and Economic Standout. Curr. Sustain. Energy Rep. 2020, 7, 122-136. [CrossRef]

6. Sara, M.; Brar, S.; Blais, J. Production of Drop-In and Novel Bio-Based Platform Chemicals. Platf. Chem. Biorefinery 2016, $249-283$. [CrossRef]

7. Sara, M.; Rouissi, T.; Brar, S.K.; Blais, J.F. Life cycle analysis of potential substrates of sustainable biorefinery. In Platform Chemical Biorefinery; Elsevier: Amsterdam, The Netherlands, 2016; pp. 55-76.

8. Van Der Pol, E.; Vaessen, E.; Weusthuis, R.A.; Eggink, G. Identifying inhibitory effects of lignocellulosic by-products on growth of lactic acid producing micro-organisms using a rapid small-scale screening method. Bioresour. Technol. 2016, 209, 297-304. [CrossRef]

9. Zhang, L.; Li, X.; Yong, Q.; Yang, S.-T.; Ouyang, J.; Yu, S. Impacts of lignocellulose-derived inhibitors on L-lactic acid fermentation by Rhizopus oryzae. Bioresour. Technol. 2016, 203, 173-180. [CrossRef]

10. Kim, D. Physico-Chemical Conversion of Lignocellulose: Inhibitor Effects and Detoxification Strategies: A Mini Review. Molecules 2018, 23, 309. [CrossRef]

11. Abdel-Rahman, M.A.; Tashiro, Y.; Zendo, T.; Sakai, K.; Sonomoto, K. Highly efficient L-lactic acid production from xylose in cell recycle continuous fermentation using Enterococcus mundtii QU 25. RSC Adv. 2016, 6, 17659-17668. [CrossRef]

12. Abdel-Rahman, M.A.; Tashiro, Y.; Sonomoto, K. Recent advances in lactic acid production by microbial fermentation processes. Biotechnol. Adv. 2013, 31, 877-902. [CrossRef] [PubMed]

13. Hassan, S.E.-D.; Abdel-Rahman, M.A.; Roushdy, M.M.; Azab, M.S.; Gaber, M.A. Effective biorefinery approach for lactic acid production based on co-fermentation of mixed organic wastes by Enterococcus durans BP130. Biocatal. Agric. Biotechnol. 2019, 20, 101203. [CrossRef] 
14. Abdel-Rahman, M.A.; Tashiro, Y.; Zendo, T.; Sakai, K.; Sonomoto, K. Enterococcus faecium QU 50: A novel thermophilic lactic acid bacterium for high-yield L-lactic acid production from xylose. FEMS Microbiol. Lett. 2015, 362, 1-7. [CrossRef] [PubMed]

15. Miller, D.N.; Bryant, J.E.; Madsen, E.L.; Ghiorse, W.C. Evaluation and optimization of DNA extraction and purification procedures for soil and sediment samples. Appl. Environ. Microbiol. 1999, 65, 4715-4724. [CrossRef] [PubMed]

16. Tanaka, K.; Komiyama, A.; Sonomoto, K.; Ishizaki, A.; Hall, S.; Stanbury, P. Two different pathways for D-xylose metabolism and the effect of xylose concentration on the yield coefficient of L-lactate in mixed-acid fermentation by the lactic acid bacterium Lactococcus lactis IO-1. Appl. Microbiol. Biotechnol. 2002, 60, 160-167. [PubMed]

17. Patel, M.A.; Ou, M.S.; Harbrucker, R.; Aldrich, H.C.; Buszko, M.L.; Ingram, L.O.; Shanmugam, K.T. Isolation and Characterization of Acid-Tolerant, Thermophilic Bacteria for Effective Fermentation of Biomass-Derived Sugars to Lactic Acid. Appl. Environ. Microbiol. 2006, 72, 3228-3235. [CrossRef]

18. Poudel, P.; Tashiro, Y.; Sakai, K. New application of Bacillus strains for optically pure L-lactic acid production: General overview and future prospects. Biosci. Biotechnol. Biochem. 2016, 80, 642-654. [CrossRef]

19. Zhou, X.; Ye, L.; Wu, J.C. Efficient production of L-lactic acid by newly isolated thermophilic Bacillus coagulans WCP10-4 with high glucose tolerance. Appl. Microbiol. Biotechnol. 2013, 97, 4309-4314. [CrossRef]

20. Meng, Y.; Xue, Y.; Yu, B.; Gao, C.; Ma, Y. Efficient production of L-lactic acid with high optical purity by alkaliphilic Bacillus sp. WL-S20. Bioresour. Technol. 2012, 116, 334-339. [CrossRef]

21. Albert, R.A.; Archambault, J.; Rossello-Mora, R.; Tindall, B.J.; Matheny, M. Bacillus acidicola sp. nov., a novel mesophilic, acidophilic species isolated from acidic Sphagnum peat bogs in Wisconsin. Int. J. Syst. Evol. Microbiol. 2005, 55, 2125-2130. [CrossRef]

22. Othman, M.; Ariff, A.B.; Rios-Solis, L.; Halim, M. Extractive fermentation of lactic acid in lactic acid bacteria cultivation: A review. Front. Microbiol. 2017, 8, 2285. [CrossRef] [PubMed]

23. Trcek, J.; Mira, N.P.; Jarboe, L.R. Adaptation and tolerance of bacteria against acetic acid. Appl. Microbiol. Biotechnol. 2015, 99, 6215-6229. [CrossRef] [PubMed]

24. Ye, L.; Zhou, X.; Bin Hudari, M.S.; Li, Z.; Wu, J.C. Highly efficient production of L-lactic acid from xylose by newly isolated Bacillus coagulans C106. Bioresour. Technol. 2013, 132, 38-44. [CrossRef] [PubMed]

25. Ou, M.S.; Mohammed, N.; Ingram, L.O.; Shanmugam, K.T. Thermophilic Bacillus coagulans requires less cellulases for simultaneous saccharification and fermentation of cellulose to products than mesophilic microbial biocatalysts. Appl. Biochem. Biotechnol. 2009, 155, 379-385. [CrossRef] [PubMed]

26. Abdel-Rahman, M.A.; Hassan, S.E.D.; Roushdy, M.M.; Azab, M.S.; Gaber, M.A. Free-nutrient supply and thermo-alkaline conditions for direct lactic acid production from mixed lignocellulosic and food waste materials. Bioresour. Technol. Rep. 2019, 7, 100256. [CrossRef]

27. Chundawat, S.P.S.; Balan, V.; Da Costa Sousa, L.; Dale, B.E. Thermochemical pretreatment of lignocellulosic biomass. In Bioalcohol Production; Woodhead Publishing: Cambridge, UK, 2010; pp. 24-72.

28. Jönsson, L.J.; Martín, C. Pretreatment of lignocellulose: Formation of inhibitory by-products and strategies for minimizing their effects. Bioresour. Technol. 2016, 199, 103-112. [CrossRef] [PubMed]

29. Ximenes, E.; Kim, Y.; Mosier, N.; Dien, B.; Ladisch, M.R. Deactivation of cellulases by phenols. Enzym. Microb. Technol. 2011, 48, 54-60. [CrossRef]

30. Xiros, C.; Olsson, L. Comparison of strategies to overcome the inhibitory effects in high-gravity fermentation of lignocellulosic hydrolysates. Biomass Bioenergy 2014, 65, 79-90. [CrossRef]

31. Van Der Pol, E.; Bakker, R.R.; Baets, P.; Eggink, G. By-products resulting from lignocellulose pretreatment and their inhibitory effect on fermentations for (bio)chemicals and fuels. Appl. Microbiol. Biotechnol. 2014, 98, 9579-9593. [CrossRef]

32. Yu, X.; Zeng, J.; Zheng, Y.; Chen, S. Effect of lignocellulose degradation products on microbial biomass and lipid production by the oleaginous yeast Cryptococcus curvatus. Process. Biochem. 2014, 49, 457-465. [CrossRef]

33. Kabel, M.A.; Bos, G.; Zeevalking, J.; Voragen, A.G.J.; Schols, H.A. Effect of pretreatment severity on xylan solubility and enzymatic breakdown of the remaining cellulose from wheat straw. Bioresour. Technol. 2007, 98, 2034-2042. [CrossRef] [PubMed]

34. Klinke, H.B.; Olsson, L.; Thomsen, A.B.; Ahring, B.K. Potential inhibitors from wet oxidation of wheat straw and their effect on ethanol production of Saccharomyces cerevisiae: Wet oxidation and fermentation by yeast. Biotechnol. Bioeng. 2003, 81, 738-747. [CrossRef] [PubMed]

35. Mills, T.Y.; Sandoval, N.R.; Gill, R.T. Cellulosic hydrolysate toxicity and tolerance mechanisms in Escherichia coli. Biotechnol. Biofuels 2009, 2, 1-11. [CrossRef] [PubMed]

36. Cortez, D.V.; Roberto, I.C. Individual and interaction effects of vanillin and syringaldehyde on the xylitol formation by Candida guilliermondii. Bioresour. Technol. 2010, 101, 1858-1865. [CrossRef] [PubMed]

37. Allen, S.A.; Clark, W.; McCaffery, J.M.; Cai, Z.; Lanctot, A.; Slininger, P.J.; Liu, Z.L.; Gorsich, S.W. Furfural induces reactive oxygen species accumulation and cellular damage in Saccharomyces cerevisiae. Biotechnol. Biofuels 2010, 3, 2. [CrossRef]

38. Larsson, S.; Quintana-Sáinz, A.; Reimann, A.; Nilvebrant, N.-O.; Jönsson, L.J. Influence of Lignocellulose-Derived Aromatic Compounds on Oxygen-Limited Growth and Ethanolic Fermentation by Saccharomyces cerevisiae. Appl. Biochem. Biotechnol. 2000, 84, 617-632. [CrossRef]

39. Adeboye, P.T.; Bettiga, M.; Olsson, L. The chemical nature of phenolic compounds determines their toxicity and induces distinct physiological responses in Saccharomyces cerevisiae in lignocellulose hydrolysates. AMB Express 2014, 4, 46. [CrossRef] 
40. Almeida, J.R.M.; Modig, T.; Petersson, A.; Hähn-Hägerdal, B.; Lidén, G.; Gorwa- Grauslund, M.F. Increased tolerance and conversion of inhibitors in lignocellulosic hydrolysates by Saccharomyces cerevisiae. J. Chem. Technol. Biotechnol. 2007, 82, 340-349. [CrossRef]

41. Walton, S.L.; Bischoff, K.M.; Van Heiningen, A.R.P.; Van Walsum, G.P. Production of lactic acid from hemicellulose extracts by Bacillus coagulans MXL-9. J. Ind. Microbiol. Biotechnol. 2010, 37, 823-830. [CrossRef]

42. Van der Pol, E.C.; Bakker, R.R.; van Zeeland, A.N.T.; Sanchez Garcia, D.; Punt, A. Eggink, G. Analysis of by-product formation and sugar monomerization in sugarcane bagasse pretreated at pilot plant scale: Differences between autohydrolysis, alkaline and acid pretreatment. Bioresour. Technol. 2015, 181, 114-123. [CrossRef] 